\title{
Power of oesophageal peristalsis can be controlled voluntarily
}

\author{
R M Valori, M T Hallisey, J Dunn
}

\begin{abstract}
The hypothesis that oesophageal peristalsis can be modified voluntarily was explored. Six healthy male volunteers and eight female patients with angina like chest pain underwent oesophageal manometry. Each was asked to take a series of swallows, and to vary their size, in random order, by taking either a big gulp or a little swallow. None of the subjects experienced difficulty in doing so. In both groups the amplitude of oesophageal contractions were significantly greater after big gulps than little swallows $(p<0.01)$ and this was true for wet $(82.0 v 68.9 \mathrm{mmHg})$ and dry swallows $(52.3 v$ $43.3 \mathrm{mmHg}$ ). For the patients' wet swallows the mean values were 73.0 and $56.0 \mathrm{mmHg}$. Thus, the amplitude of oesophageal peristalsis can be controlled voluntarily. This effect may account for some of the within subject variation in the amplitude of oesophageal contractions. During oesophageal manometry subjects should be encouraged to standardise the size of their swallows whenever possible. Patients with symptoms related to abnormal oesophageal peristalsis such as dysphagia, heartburn, and chest pain may benefit from biofeedback training.
\end{abstract}

It is now accepted that changes in the amplitude of oesophageal peristaltic contractions can cause symptoms. ${ }^{1-3}$ Low amplitude contractions can cause dysphagia' and may lead to ineffective clearance of acid from the oesophagus ${ }^{2}$ and thus to symptoms of oesophageal reflux and oesophagitis. High amplitude contractions, so-called 'nutcracker' oesophagus, can cause angina like chest pain. ${ }^{3}$ Hence, modification of the power of oesophageal contractions may be therapeutically useful. This study explored the possibility that

Departments of Medicine and Surgery, and West

Midlands Cancer

Research Campaign,

Clinical Trials Unit,

Queen Elizabeth

Hospital, Edgbaston,

Birmingham

R M Valori

$M$ T Hallisey

J Dunn

Correspondence to:

Dr Roland Valori.

Accepted for publication

14 May 1990 the amplitude of oesophageal peristalsis could be altered voluntarily.

\section{Methods}

\section{SUBJECTS}

\section{Healthy volunteers}

These were subjects with no history of chest pain, dyspepsia, or other gastrointestinal symptoms.

\section{Patients}

These were patients with angina like chest pain but without evidence of ischaemic heart disease (excluded with exercise electrocardiogram or coronary angiography, or both). Before manometry for investigation of chest pain, each subject was asked if she would perform an additional 20 wet swallows. The exact nature of the swallows was not explained until routine manometry was completed.

\section{OESOPHAGEAL MANOMETRY}

Oesophageal manometry was performed with either a perfused tube (healthy volunteers) or transducers in situ (patients).

\section{Perfused tube manometry}

A $5 \mathrm{~mm}$ diameter, multilumen manometry catheter, with three perfusion ports spaced $5 \mathrm{~cm}$ apart, was perfused with a low compliance pneumo hydraulic system (Arndorfer Medical Specialities, Greendale, Wisconsin, USA). Signals from externally placed transducers were recorded using a Synectics polygraph system (Synectics, 215 Willow Road, Enfield, EN1 3BT). The amplitude, duration, and propagation velocity of contractions were analysed by an observer, blind to the order of randomised swallows, using an upper gastrointestinal motility software program (Synectics).

\section{Transducers in situ}

A $2 \mathrm{~mm}$ diameter cable with three miniature transducers mounted $5 \mathrm{~cm}$ apart (Gaeltec Ltd, Dunvegan, Isle of Skye, Scotland IV55 8GU) was connected to a lectromed polygraph system (Ormed Ltd, 32 Hydeway, Welwyn Garden City, Herts AL7 3AW) and the pressure changes were recorded on heat sensitive paper. The recordings were analysed manually by an observer, blind to the order of swallows, using a standard technique. ${ }^{+}$

\section{Statistics ${ }^{56}$}

The data were stored on a dual VAX 3600 system (WMCRCCTU) and analysed using the BMDP statistical package. ${ }^{5}$ Exploratory data analysis showed that the data had no significant skew or 
TABLE I Analysis of variance statistics for amplitude of peristalsis

\begin{tabular}{|c|c|c|}
\hline & $F$ & $P$ \\
\hline \multicolumn{3}{|l|}{ Volunteers } \\
\hline Wet $v$ Dry (Type-T) & $354 \cdot 07$ & 0.0000 \\
\hline Little $v$ big (Gulp-G) & 56.81 & 0.0000 \\
\hline TG & $2 \cdot 44$ & $0 \cdot 1208$ \\
\hline Channel C & $51 \cdot 89$ & 0.0000 \\
\hline TC & $48 \cdot 52$ & 0.0000 \\
\hline GC & $3 \cdot 86$ & 0.0280 \\
\hline TGC & 0.47 & 0.5984 \\
\hline \multicolumn{3}{|l|}{ Patients (wet swallow only) } \\
\hline Little $v$ big (gulp) & $20 \cdot 12$ & 0.0000 \\
\hline Channel & $64 \cdot 42$ & 0.0000 \\
\hline GC & 4.90 & 0.0124 \\
\hline \multicolumn{3}{|c|}{ Patient $v$ control (wet swallow only) } \\
\hline Patient $v$ control (case) & 4.93 & 0.0276 \\
\hline Little $v$ big (gulp) & $62 \cdot 83$ & 0.0000 \\
\hline Case $x$ gulp & 1.09 & 0.2967 \\
\hline Channel & $135 \cdot 18$ & 0.0000 \\
\hline C $x$ case & 1.96 & $0 \cdot 1460$ \\
\hline C x gulp & $8 \cdot 29$ & 0.0006 \\
\hline Gulp $x$ case $x$ channel & 1.35 & 0.2602 \\
\hline
\end{tabular}

kurtosis. Cell means were plotted against the factors of interest to explore two way interactions. Histograms of the replicates suggested that a repeated measures analysis of variance was appropriate, and program $2 \mathrm{~V}$ was used.

The BMDP 2V analysis of variance with repeated measures program was used to analyse the volunteer data by type of swallow (wet and dry) and by swallow size (big and little) across three channels (repeated measures) (Table I). The patient data were analysed for wet swallows only, by swallow size across three channels (repeated measures). Finally, patient and volunteer data were analysed by swallow size for wet swallows across three channels.

To determine whether one swallow type produced less variation the ratio of the two variance estimates $\left(\mathrm{S}_{1}{ }^{2} / \mathrm{S}_{2}{ }^{2}\right)$ was calculated for each channel and for each subject in turn. ${ }^{6}$ The ratio of the two variance estimates for the amplitude follow an $F$ distribution, and to reach $95 \%$ level of significance for a two tailed test the $F$ ratio $F(19,19)$ must be greater than 2.6 for volunteers and the $F$ ratio $F(9,9)$ must be greater than $4 \cdot 1$ for patients.

\section{Experimental protocol}

In both patient and volunteer studies the motility probes were positioned so that the distal sensor lay $3 \mathrm{~cm}$ above the upper level of the lower oesophageal sphincter. The probe was then anchored by taping it to the subject's nose. The volunteers were positioned supine and asked to perform 40 wet swallows ( $5 \mathrm{ml}$ water) and 40 dry swallows. The patients were asked to perform 20 wet swallows $(5 \mathrm{ml})$ while sitting upright. An interval of at least 30 seconds was allowed between swallows.

For each swallow the subject was instructed to take either a big gulp or a little swallow. The order of gulps and swallows was randomised. For the big gulps the subjects were asked to increase the effort employed in swallowing and to try to imagine swallowing a large object. For the little swallows they were asked to swallow with minimal effort sufficient to initiate swallow (dry) or to clear the mouth of water (wet). The subjects were also asked to try to avoid swallowing air.

\section{Results}

\section{HEALTHY VOLUNTEERS}

Six men (age range $30-38$, mean $=34$ years) each performed 40 wet and 40 dry swallows in random order. The mean amplitude of contractions for wet and dry swallows for each subject is summarised in Table II. The amplitude of wet swallows was significantly greater than that for dry swallows $(\mathrm{p}<0.01)$ and contractions in the lower oesophagus were stronger $(<0 \cdot 01)$. The big gulps produced more powerful oesophageal contractions than the little swallows $(p<0.01)$. There was no difference in the magnitude of the effect of swallow type between wet and dry swallows $(p=0 \cdot 12)$. There was a significant interaction between swallow type and channel $(p=0.028)$ and plotting the values suggested that the upper oesophagus was more sensitive to the effect of swallow type. There were no differences in the duration or propagation velocity of contractions.

\section{PATIENTS}

Eight female patients (age range 34-58, mean $=51$ years) with angina like chest pain performed 20 wet swallows. Table III summarises the amplitude data for the patients. The changes were similar to those for the volunteers' wet swallows. The amplitude of contractions was greater in the distal oesophagus $(\mathrm{p}<0 \cdot 01)$, and big gulps pro-

TABLE II Summary of amplitude data for the healthy volunteers. Each mean (SD) represents 20 swallows. C1, C2, and C3 refer to channels 1,2 , and 3

\begin{tabular}{|c|c|c|c|c|c|c|c|c|c|c|c|c|}
\hline \multirow[t]{3}{*}{ Volunteers } & \multicolumn{6}{|c|}{ Dry Swallows } & \multicolumn{6}{|c|}{ Wet swallows } \\
\hline & \multicolumn{3}{|l|}{$\overline{\text { Little }}$} & \multicolumn{3}{|l|}{ Big } & \multicolumn{3}{|l|}{$\overline{\text { Little }}$} & \multicolumn{3}{|l|}{ Big } \\
\hline & $C 1$ & $C 2$ & C3 & $C 1$ & $C 2$ & $C 3$ & $C 1$ & $C 2$ & C3 & $C 1$ & $C 2$ & C3 \\
\hline 1 & $24 \cdot 3$ & $33 \cdot 8$ & $32 \cdot 2$ & $21 \cdot 4$ & $22 \cdot 1$ & $27 \cdot 6$ & $29 \cdot 1$ & $40 \cdot 3$ & $36 \cdot 1$ & $45 \cdot 2$ & $63 \cdot 1$ & $66 \cdot 8$ \\
\hline & $(9 \cdot 5)$ & $(15 \cdot 1)$ & $(16 \cdot 4)$ & $(8.9)$ & $(13 \cdot 1)$ & $(14 \cdot 9)$ & $(13 \cdot 2)$ & $(15 \cdot 7)$ & $(17 \cdot 8)$ & $(11 \cdot 4)$ & $(5 \cdot 3)$ & $(15 \cdot 6)$ \\
\hline 2 & $\begin{array}{c}60 \cdot 7 \\
(14 \cdot 1)\end{array}$ & $\begin{array}{c}67 \cdot 4 \\
(10 \cdot 7)\end{array}$ & $\begin{array}{c}74 \cdot 4 \\
(21 \cdot 5)\end{array}$ & $\begin{array}{c}60 \cdot 5 \\
(19 \cdot 1)\end{array}$ & $\begin{array}{c}70.8 \\
(10.3)\end{array}$ & $\begin{array}{c}86.9 \\
(25 \cdot 3)\end{array}$ & $\begin{array}{c}76 \cdot 4 \\
(12 \cdot 8)\end{array}$ & $\begin{array}{l}87 \cdot 3 \\
(12 \cdot 3)\end{array}$ & $\begin{array}{l}111 \cdot 2 \\
(21 \cdot 2)\end{array}$ & $\begin{array}{l}78 \cdot 0 \\
(6 \cdot 3)\end{array}$ & $\begin{array}{l}98 \cdot 1 \\
(7 \cdot 5)\end{array}$ & $\begin{array}{l}131 \cdot 6 \\
(16 \cdot 7)\end{array}$ \\
\hline 3 & $\begin{array}{c}23.9 \\
(6.3)\end{array}$ & $\begin{array}{r}41 \cdot 2 \\
(15 \cdot 6)\end{array}$ & $\begin{array}{c}26 \cdot 8 \\
(13 \cdot 2)\end{array}$ & $\begin{array}{l}25.4 \\
(6.8)\end{array}$ & $\begin{array}{c}46.5 \\
(13.4)\end{array}$ & $\begin{array}{c}36 \cdot 3 \\
(19 \cdot 6)\end{array}$ & $\begin{array}{c}49 \cdot 1 \\
(19 \cdot 5)\end{array}$ & $\begin{array}{l}31 \cdot 7 \\
(3 \cdot 7)\end{array}$ & $\begin{array}{c}63.9 \\
(22.7)\end{array}$ & $\begin{array}{l}51.8 \\
(5.8)\end{array}$ & $\begin{array}{c}43 \cdot 3 \\
(10 \cdot 4)\end{array}$ & $\begin{array}{l}90.5 \\
(9.6)\end{array}$ \\
\hline 4 & $\begin{array}{l}24 \cdot 6 \\
(8 \cdot 5)\end{array}$ & $\begin{array}{c}23.8 \\
(18.5)\end{array}$ & $\begin{array}{c}45 \cdot 1 \\
(26 \cdot 4)\end{array}$ & $\begin{array}{r}29.9 \\
(10.3)\end{array}$ & $\begin{array}{r}33 \cdot 4 \\
(16 \cdot 3)\end{array}$ & $\begin{array}{c}54 \cdot 5 \\
(22 \cdot 1)\end{array}$ & $\begin{array}{c}22 \cdot 2 \\
(17 \cdot 3)\end{array}$ & $\begin{array}{r}54 \cdot 3 \\
(15 \cdot 5)\end{array}$ & $\begin{array}{c}90.0 \\
(14.5)\end{array}$ & $\begin{array}{l}25 \cdot 5 \\
(7 \cdot 2)\end{array}$ & $\begin{array}{l}64 \cdot 5 \\
(9 \cdot 9)\end{array}$ & $\begin{array}{r}88 \cdot 8 \\
(18.9)\end{array}$ \\
\hline 5 & $\begin{array}{c}44 \cdot 8 \\
(14 \cdot 9)\end{array}$ & $\begin{array}{r}30.5 \\
(13.4)\end{array}$ & $\begin{array}{c}63 \cdot 1 \\
(31 \cdot 8)\end{array}$ & $\begin{array}{r}49.5 \\
(13.9)\end{array}$ & $\begin{array}{r}39.6 \\
(13.4)\end{array}$ & $\begin{array}{c}77 \cdot 0 \\
(30 \cdot 9)\end{array}$ & $\begin{array}{c}60 \cdot 4 \\
(15 \cdot 7)\end{array}$ & $\begin{array}{r}83.9 \\
(14 \cdot 3)\end{array}$ & $\begin{array}{l}127 \cdot 3 \\
(21 \cdot 5)\end{array}$ & $\begin{array}{c}65 \cdot 3 \\
(15 \cdot 4)\end{array}$ & $\begin{array}{l}80.8 \\
(19.9)\end{array}$ & $\begin{array}{l}121 \cdot 5 \\
(38 \cdot 4)\end{array}$ \\
\hline 6 & $66 \cdot 5$ & 61.1 & $\begin{array}{l}35 \cdot 7 \\
(29.0)\end{array}$ & $102 \cdot 1$ & 90.3 & 66.4 & 87.6 & 113.4 & $\begin{array}{c}76.5 \\
(32.7)\end{array}$ & $120 \cdot 2$ & 141.9 & 99.7 \\
\hline Means & 40.8 & $\begin{array}{r}43.0 \\
43.3\end{array}$ & $46 \cdot 2$ & $48 \cdot 1$ & $\begin{array}{l}50.5 \\
52.2\end{array}$ & $58 \cdot 1$ & $54 \cdot 1$ & $\begin{array}{l}68.5 \\
68.9\end{array}$ & $84 \cdot 2$ & $64 \cdot 3$ & $\begin{array}{l}82 \cdot 0 \\
82 \cdot 0\end{array}$ & 99.8 \\
\hline
\end{tabular}


TABLE III Summary of amplitude data for the patients. Each mean $(S D)$ represents 10 swallows. $C 1, C 2$, and $C 3$ refer to channels 1,2 , and 3

\begin{tabular}{|c|c|c|c|c|c|c|}
\hline \multirow{3}{*}{ Patients } & \multicolumn{6}{|c|}{ Wet swallows } \\
\hline & \multicolumn{3}{|l|}{ Little } & \multicolumn{3}{|l|}{ Big } \\
\hline & $\mathrm{Cl}$ & $\mathrm{C} 2$ & $\mathrm{C} 3$ & $\mathrm{Cl}$ & $\mathrm{C} 2$ & C3 \\
\hline 1 & $\begin{array}{l}15 \cdot 8 \\
(4 \cdot 9)\end{array}$ & $\begin{array}{l}25 \cdot 6 \\
(4 \cdot 3)\end{array}$ & $\begin{array}{c}37 \cdot 8 \\
(21 \cdot 4)\end{array}$ & $\begin{array}{l}21 \cdot 2 \\
(7 \cdot 6)\end{array}$ & $\begin{array}{c}29 \cdot 0 \\
(6 \cdot 1)\end{array}$ & $\begin{array}{c}68 \cdot 7 \\
(22 \cdot 6)\end{array}$ \\
\hline 2 & $\begin{array}{l}12 \cdot 5 \\
(5 \cdot 0)\end{array}$ & $\begin{array}{c}42 \cdot 4 \\
(18 \cdot 1)\end{array}$ & $\begin{array}{c}77 \cdot 1 \\
(15 \cdot 3)\end{array}$ & $\begin{array}{l}16 \cdot 3 \\
(2 \cdot 9)\end{array}$ & $\begin{array}{c}65 \cdot 7 \\
(11 \cdot 6)\end{array}$ & $\begin{array}{l}99.7 \\
(23.6)\end{array}$ \\
\hline 3 & $\begin{array}{c}35 \cdot 6 \\
(12 \cdot 7)\end{array}$ & $\begin{array}{c}28 \cdot 2 \\
(12 \cdot 3)\end{array}$ & $\begin{array}{c}37 \cdot 4 \\
(13 \cdot 8)\end{array}$ & $\begin{array}{l}41 \cdot 8 \\
(9 \cdot 5)\end{array}$ & $\begin{array}{l}27 \cdot 5 \\
(7 \cdot 0)\end{array}$ & $\begin{array}{l}35.5 \\
(9.9)\end{array}$ \\
\hline 4 & $\begin{array}{l}119 \cdot 0 \\
(61 \cdot 3)\end{array}$ & $\begin{array}{l}141 \cdot 6 \\
(72 \cdot 3)\end{array}$ & $\begin{array}{l}142.9 \\
(72 \cdot 4)\end{array}$ & $\begin{array}{l}170 \cdot 1 \\
(18 \cdot 6)\end{array}$ & $\begin{array}{l}199.3 \\
(10.9)\end{array}$ & $\begin{array}{l}204 \cdot 3 \\
(42 \cdot 6)\end{array}$ \\
\hline 5 & $\begin{array}{c}63 \cdot 7 \\
(11 \cdot 9)\end{array}$ & $\begin{array}{l}102 \cdot 4 \\
(30 \cdot 1)\end{array}$ & $\begin{array}{l}118 \cdot 7 \\
(19 \cdot 5)\end{array}$ & $\begin{array}{c}69 \cdot 3 \\
(12 \cdot 7)\end{array}$ & $\begin{array}{c}150 \cdot 1 \\
(8 \cdot 9)\end{array}$ & $\begin{array}{l}124 \cdot 5 \\
(12 \cdot 8)\end{array}$ \\
\hline 6 & $\begin{array}{l}24 \cdot 8 \\
(6 \cdot 3)\end{array}$ & $\begin{array}{c}52 \cdot 3 \\
(17 \cdot 1)\end{array}$ & $\begin{array}{c}43.3 \\
(14.6)\end{array}$ & $\begin{array}{l}26 \cdot 6 \\
(6.9)\end{array}$ & $\begin{array}{c}67 \cdot 7 \\
(14 \cdot 0)\end{array}$ & $\begin{array}{c}70 \cdot 3 \\
(14 \cdot 1)\end{array}$ \\
\hline 7 & $\begin{array}{c}32 \cdot 1 \\
(15 \cdot 2)\end{array}$ & $\begin{array}{c}38 \cdot 5 \\
(24 \cdot 8)\end{array}$ & $\begin{array}{c}28 \cdot 6 \\
(11 \cdot 1)\end{array}$ & $\begin{array}{c}42.5 \\
(22 \cdot 7)\end{array}$ & $\begin{array}{c}44 \cdot 6 \\
(23 \cdot 0)\end{array}$ & $\begin{array}{c}39.9 \\
(17 \cdot 7)\end{array}$ \\
\hline 8 & $\begin{array}{c}29 \cdot 8 \\
(12 \cdot 1)\end{array}$ & $\begin{array}{c}38 \cdot 6 \\
(19 \cdot 8)\end{array}$ & $\begin{array}{c}53.3 \\
(29 \cdot 1)\end{array}$ & $\begin{array}{c}26 \cdot 1 \\
(15 \cdot 7)\end{array}$ & $\begin{array}{c}44 \cdot 3 \\
(25 \cdot 1)\end{array}$ & $\begin{array}{c}67 \cdot 2 \\
(32 \cdot 1)\end{array}$ \\
\hline $\begin{array}{l}\text { Means } \\
\text { Grand } \\
\text { means }\end{array}$ & $41 \cdot 7$ & $\begin{array}{l}58 \cdot 7 \\
56 \cdot 0\end{array}$ & $67 \cdot 7$ & $51 \cdot 7$ & $\begin{array}{l}78 \cdot 5 \\
73 \cdot 0\end{array}$ & 88.8 \\
\hline
\end{tabular}

duced more powerful contractions than little swallows $(\mathrm{p}<0.01)$. There was a similar interaction between swallow type and channel $(p=0.012)$. The change in amplitude (in response to different swallow type) was greater in the patient group than in the volunteer group but the difference was not significant $(p=30)$. By increasing the swallow effort, one patient increased the mean amplitude of 10 swallows (distal two channels) from 142 to $202 \mathrm{mmHg}$. This change would have reclassified the patient from the normal into the 'nutcracker' range (mean amplitude in distal two channels $>180 \mathrm{mmHg} .{ }^{7}$ There were no differences in the duration or propagation velocity of contractions.

While measurements of the baseline manometry in the patients was not part of the original protocol, it is of interest to compare the baseline amplitude with the amplitude of the modified swallows. The means for all three methods of swallowing (little swallow, baseline, and big gulp) are summarised in Table IV. Two way analysis of variance showed a significant difference between baseline swallows and big gulps $(p<0.01)$. The overall difference between little swallows and baseline swallows was not significant $(p=0 \cdot 16)$, but when differences in separate channels were examined, baseline swallows in channel 2 were significantly stronger $(p=0.028)$. The baseline amplitude (distal two channels) of the patient with possible nutcracker oesophagus was $148 \mathrm{mmHg}$.

\section{VARIATION}

The variation in amplitude for different swallow types in the patients' swallows and the volunteers' dry swallows was very similar except for

TABLE IV Mean amplitude (in $\mathrm{mmHg}$ ) of 10 wet swallows ( $5 \mathrm{ml}$ water) in each channel for little swallows, baseline manometry, and big gulps

\begin{tabular}{llll}
\hline & \multicolumn{3}{l}{ Channel } \\
\cline { 2 - 4 } & 1 & 2 & 3 \\
\hline Little swallows & $41 \cdot 7$ & $58 \cdot 7$ & $67 \cdot 7$ \\
Baseline & $43 \cdot 3$ & $67 \cdot 8$ & $70 \cdot 1$ \\
Big gulps & $51 \cdot 7$ & $78 \cdot 5$ & $88 \cdot 8$ \\
\hline
\end{tabular}

one patient in whom one ratio was greater than $4 \cdot 1$ in two channels (in favour of a big gulp). However, for the volunteers' wet swallows eight of 18 channels (three times six subjects) showed ratios greater than 2.6 in favour of big gulps and one of 18 in favour of little swallows. Thus, big gulps in the volunteers produced significantly less variation in the amplitude of peristalsis. Finally, as might be expected, the variation of all swallows was much greater than that of individual swallow types.

\section{Discussion}

Much importance has been placed upon the characteristics of the oesophageal pressure wave in the investigation of function and pathology of the oesophagus. ${ }^{17}$ Abnormalities of amplitude are thought to cause symptoms. ${ }^{23}$ This study has shown that the amplitude of oesophageal peristalsis can be modified by changing the effort used in swallowing. This finding may affect the method and interpretation of oesophageal manometry in the future and may also have therapeutic implications for the control of oesophageal symptoms.

The manometric differences between big gulps and little swallows were apparent for both wet and dry swallows, as well as for both volunteers and patients. There was no difference in magnitude of effect between wet and dry. While the change was not significant, the patients increased the amplitude of their swallows more consistently than did the volunteers. This difference between patients and volunteers could be due to posture, to probe size, or to the subject. It may be easier to modify swallow size while sitting upright $^{8}$ or with a smaller foreign body in the pharynx. Alternatively, patients, who in this study were older and all women, may be more proficient at changing their swallow size.

There has been one previous report of the effects of swallowing effort on oesophageal peristalsis. ${ }^{9}$ An increase in the amplitude of oesophageal peristalsis was recorded with stronger swallows but the change failed to reach statistical significance. In that study, the effect of effort was only examined on dry swallows, and comparisons were made between maximum and average effort. When we compared baseline amplitudes (average effort) in our patient group with those of maximum (big gulp) and minimum (little swallow) effort, most values (54\%) lay between these two means. Thus, failure to compare maximum with minimum effort, use of dry swallows, or chance may explain the difference between the two studies.

Differences in the oesophageal response to wet and dry swallows have been attributed to a bolus effect with wet swallows. ${ }^{10}$ It could be argued that in the present study swallowing air with the more powerful swallows caused a bolus effect which lead to an increase in the amplitude of peristalsis. While this may have occurred with the dry swallows it is unlikely to have done so with the wet swallows. Previous studies have shown that larger volumes of water $(20 \mathrm{ml})$ do not significantly alter the amplitude of contractions.9 Therefore, unless quite large volumes of air were swallowed the amplitude of wet swallows 
should not have been affected by air. The subjects were specifically asked to try to avoid swallowing air and after the study all confirmed that they had not been aware of swallowing air with the larger swallows. Furthermore, only one subject noticed an excess of wind after the study (a volunteer in whom the difference in amplitude was the fifth largest of six). To explore this possibility further it would be necessary to measure intestinal gas ${ }^{11}$ during and after a study, with and without powerful swallows. It could also be argued that little swallows lead to more 'double swallows' and that these may have lead to the reduced amplitude in this group. We did not monitor swallowing, but neither subjects nor observers were aware of an excess of double swallows in either group.

The control of oesophageal peristalsis is thought to involve vagal, intramural, and myogenic mechanisms. ${ }^{12}$ Furthermore, the amplitude of peristalsis seems to be dependent upon cholinergic activity. ${ }^{1314}$ If there is no bolus effect, the increase in amplitude shown in this study could have been mediated directly by pharyngooesophageal intramural pathways or indirectly by either pharyngeal or cortical stimulation of the vagus. It would make sense for the oesophagus to have warning of how powerfully it need contract to ensure clearance with one swallow.

Because of intrasubject variation in the amplitude of peristalsis it is recommended that the amplitude of peristalsis should be estimated from the mean of 10 swallows. ${ }^{4}$ Some of this variation may be due to varying the effort employed in swallowing. In our data there was a significant difference in the variation of little swallows and of big gulps for the volunteers' wet swallows but not, with one exception, for the patients' swallows. Therefore, we cannot recommend that investigators ask their patients to maximise or minimise their swallowing effort to reduce variation. However, the variation of all swallows was much greater than of little swallows or of big gulps alone, so, it would seem advisable to ask subjects to try to keep the effort of swallowing constant.

There is controversy about the importance of the nutcracker oesophagus. ${ }^{15}$ In our study, the mean amplitude of 10 wet swallows in one patient with atypical chest pain increased into the nutcracker range when the patient was asked to increase the force of her swallows. As a group, patients probably find oesophageal intubation more stressful than subjects who volunteer. This added stress may lead to more forceful swallows and spuriously high estimations of amplitude. ${ }^{16}$ Thus, high amplitude contractions in some of these patients may be a stress related artefact.
The finding, on further manometry, of normal peristaltic pressure in up to $47 \%$ of patients with the nutcracker oesophagus ${ }^{17}$ supports the hypothesis of a stress related artefact occurring during the first study.

The most important clinical application of this study is the potential for treating symptoms using biofeedback control of oesophageal peristalsis. If the nutcracker oesophagus and low amplitude peristalsis are important factors in the genesis of chest pain, ${ }^{3}$ heartburn ${ }^{2}$ and dysphagia, ${ }^{1}$ then conscious control of the amplitude of peristalsis should be useful for treatment of these symptoms. It is easy for a subject to observe his own oesophageal contractions, therefore the amplitude of contractions should be amenable to biofeedback control. Further studies designed to explore this treatment model are now warranted.

We thank Dr R Nagle for allowing us to study his patients, Mr D Farrar and Dr R Cockel for loan of manometry equipment. Dr Krys Kelly for statistical advice, and Miss Joanne Wormington for typing the manuscript.

1 Clouse RE. Esophagus: motor disorders. In: Sleisenger M, Fordtran J, eds. Gastrointestinal disease. Pathophysiology, diagnosis and management. Philadelphia: WB Saunders, 1989: diagnosis

2 Kahrilas PJ, Dodds WJ, Hogan WJ. Effect of peristaltic dysfunction on esophageal volume clearance. Gastroenterology 1988; 94: 73-80.

3 Katz PO, Dalton CB, Richter JE, Wu WC, Castell DO. Esophageal testing of patients with noncardiac chest pain or dysphagia. Ann Int Med 1987; 106: 593-7.

4 Dalton $\mathrm{CB}$. Measurements and interpretations. In: Castell DO, Richter JE, Dalton CB, eds. Esophageal motility testing. New York: Elsevier, 1987: 61-78.

5 BMDP statistical software manual volumes $1 \& 2$. Los Angeles, California 90025: BMDP Statistical Software, Inc, Angeles,

6 Armitage P. Statistical methods in medical research. Oxford: Blackwell Scientific, 1971: 140-3.

7 Janssens J, Vantrappen G, Ghillebert G. 24-Hour recording of esophageal pressure and $\mathrm{pH}$ in patients with noncardiac chest pain. Gastroenterology 1986; 90: 1978-84.

8 Kaye MD, Wexler RM. Alteration of esophageal peristalsis by body position. Dig Dis Sci 1981; 26: 897-901

9 Hollis JB, Castell DO. Effect of dry swallows and wet swallows of different volumes on esophageal peristalsis. $\mathcal{F}$ Appl Physiol 1975; 38: 1161-4.

10 Dodds WJ, Hogan WJ, Reid DP, Stewart ET, Arndofer RC. A comparison between primary esophageal peristalsis following wet and dry swallows. F Appl Physiol 1973; 35: 851-7.

11 Tomlin J, Lowis C, Read NW. Characterisation of rectal flatus. Gut 1989; 30: A1479.

12 Diamant NE. Physiology of the esophagus. In: Sleisenger M, Fordtran J, eds. Gastrointestinal disease. Pathophysiology, diagnosis and management. Philadelphia, WB Saunders, $1989 ; 548-59$

13 Dodds WJ, Dent J, Hogan WJ, Arndorfer RC. The effect of atropine on esophageal motor function in man. Gastroenterology 1978; 74: 1028

14 Dodds WJ, Christensen J, Dent J, Arndorfer RC, Wood JD. Pharmacologic investigation of primary peristalsis in the smooth-muscle portion of the opossum esophagus. $A m \mathcal{F}$ Physiol 1979; 237: E561-5.

15 Cohen S. Esophageal motility disorders and their response to calcium channel antagonists: the sphinx revisited. Gastroenterology 1987; 93: 201-3.

16 Anderson KO, Dalton CB, Bradley LA, Richter JE. Stress induces alteration of esophageal pressure in healthy volunteers and

17 Dalton CB, Castell DO, Richter JE. The changing face of the nutcracker esophagus. Am F Gastroenterol 1988; 83: 358-61. 